\title{
TOWARDS A RELIGIOUSLY HYBRID IDENTITY? The Changing Face of Javanese Islam
}

\author{
Masdar Hilmy \\ UIN Sunan Ampel, Surabaya - Indonesia | masdar.hilmy@gmail.com
}

\begin{abstract}
This article seeks to revisit the discussion of Javanese Islam from an alternative point of view. It argues that the presentation of Javanese Islam in the previous studies is no longer adequate to accommodate the most current transformation of Javanese Islam. The identity of Javanese Islam can neither be seen from syncretic point of view nor normative perspective per se, since the identity of Javanese Islam has transformed itself into something different from the past. Becoming an abangan or santri in the post-Geertz era, represents the making of a religiously hybrid identity. In the context of Geertz, to become an abangan means he/she cannot become a santri at once. At that time, a pure and puritan abangan, was hardly a practicing Muslim, but nominal Muslim. Becoming a santri, on the other hand, had to be done by disentangling any type of identity in kejawen sense. Javanese Islam has to do with whatever-you-like mentality that forms a hybrid identity among the Javanese Muslims.
\end{abstract}

Keywords: Javanese Islam, kejawen/abangan, santri, hybrid identity.

\section{Introduction}

Javanese Islam has long been the subject of academic debate among scholars and social scientists. One of the most frequently debated issues in this context is, inter alia, who and what constitutes Javanese Islam. To this question, suffice it to say that there are two opposing poles of thought. On the one hand, there is the so-called Geertzian pole arguing that Javanese Islam is a version of religion different from its counterpart in Arabian Peninsula. ${ }^{1}$ According to this

${ }^{1}$ Clifford Geertz, The Religion of Java (New York: Glencoe Press, 1960). 
pole, Javanese Islam is a distorted version of religion due to its contamination with local Javanese culture. Geertz presented the profile of Javanese Islam in a syncretic sense comprising three major elements as follows: abangan (nominal Muslims), santri (devout Muslims), and priyayi (Javanese aristocrats).

There is an opposite view to that of Geertz, written several years later and not representing the same breadth or depth of analytical force as did Geertz's work. This is the idea that Javanese Islam is the same religion as its counterpart elsewhere due to the fact that Javanese Islam is derived from the same normative root. Woodward represents this rather simplistic interpretation. ${ }^{2}$ In his opinion, the Javanese Islam can be seen as the juncture where normative piety as sanctioned in its sacred texts, i.e. the Qur'an and Hadith, meet with local values and rituals mainly preoccupied by Sufi mystical interpretation. The slametan, labeled by Geertz as the prototype of a syncretic Javanese ritual, is taken by Woodward as an example of how the Javanese Muslims interpret the standard Islamic piety into the code of conduct of Javanese tradition.

Leaving aside the two competing standpoints above, this article tries to seek the third alternative by arguing that the concept of Javanese Islam has transformed into a hybrid identity different from each of those opinions above due to Islamization and acculturation process at once. This argument leads to the assumption that neither of the two represents the most authentic self of the Javanese Islam today. Whereas Geertz's notion of Javanese Islam is colored by his subjectivity about being an authentic Islam vis-à-vis syncretic and nominal Islam, Woodward's standpoint equaling the Javanese Islam to normative Islam tends to undermine the reality of acculturation process among the Javanese Muslims.

\section{Paradigmatic Loophole}

It must be acknowledged from the outset that both the proponents of syncretic and normative standpoints of Javanese Islam fall under one same theoretical approach: that of Weberian. ${ }^{3}$ This means that

\footnotetext{
2 Mark R. Woodward, Islam in Java: Normative Piety and Mysticism in the Sultanate of Yogyakarta (Arizona: University of Arizona Press, 1989).

${ }^{3}$ For further accounts on Weberian approach, see, among others, Randall Collins, Weberian Sociological Theory (Cambridge \& New York: Cambridge University Press,
} 
regardless of the diametrical difference in argument, both Geertz and Woodward use Weberian approach that places the analysis of religion on cultural basis. Under this approach, Islam is viewed as a closed entity immune to change. Due to this reason, the entity of Javanese Islam is assumed to hold values and norms that are specific and unique different to one another. As a result, the narrative of the Javanese Islam tends to be value-heavy, apart from the analysis of geographical determinism that is also crucial in the making of Javanese Islam. ${ }^{4}$ This is so due to the fact that Weberian analysis weighs more on intrinsic aspects of religion rather than extrinsic ones such as the structural analysis of political economy of religion.

As far as the study of Javanese Islam is concerned, the theoretical approach outside Weberian approach such as Marxian or neo-Marxian approach is hardly employed. ${ }^{5}$ Scholars of the studies of Java and Islam after Geertz-such as Andrew Beatty, ${ }^{6}$ Woodward, Robert Hefner-seem unable to avoid the use of this approach. As a result, the analysis of those scholars falls into the superiority of cultural valuebased analysis over sociological power-relation. Among those scholars, it is perhaps only Hefner who attempted to cope with the hegemony of Weberian approach into Islam, even though he in the end cannot avoid the use of this approach. ${ }^{7}$ In his analysis, Hefner touches upon how the mechanism of political economy plays its role in the massive conversion among the Javanese people from Hindu-Buddhism into Islam, a phenomenon that he sees only happens in the agrarian society like the people of Java.

1986); see also, Sam Whimster, Understanding Weber (London \& New York: Routledge, 2007).

${ }^{4}$ For further account on geographical determinism, see, among others, Werner Stark, Sociology of Knowledge: Towards a Deeper Understanding of the History of Ideas (New Brunswick \& London: Transaction Publishers, 1991), especially pp. 213-244.

${ }^{5}$ For more detailed description on Marxian approach, see, for instance, John F. Sitton, Recent Marxian Theory: Class Formation and Social Conflict in Contemporary Capitalism (Albany: State University of New York Press, 1996).

6 Andrew Beatty, "Adam and Eve and Vishnu: Syncretism in the Javanese Slametan", Journal of the Royal Anthropological Institute, Vol. 2/No. 2 (1996): 271-288; See, also, Andrew Beatty, Varieties of Javanese Religion: An Anthropological Account (Cambridge \& New York: Cambridge University Press, 1999).

7 Robert W. Hefner, The Political Economy of Mountain Java: An Interpretive History (Berkeley and Los Angeles, California: University of California Press, 1990). 
Unlike the Weberian analysis that puts its heavy emphasis on the importance of culture, ${ }^{8}$ the Marxian or neo-Marxian analysis works on the major assumption that structure does matter. ${ }^{9}$ In the context of Javanese Islam, the Marxian or neo-Marxian analysis will take noncultural aspects such as politics, economy and institutions into serious account. Such an analysis would go beyond the importance of culture as an autonomous aspect in the making of Javanese Islam. Rather, it is structures that forge all culture-related aspects such as norms and values. What is meant by structure in this context is all aspects outside of religion such as opportunity structure, political economy structure, institutional structure as well as authoritative structure. It is unfortunate that most of the scholars of Javanese Islam in the era of Geertz and after exploited the Weberian approach more instead of Marxian or neo-Marxian counterpart so that the result of their analysis puts cultural values above all structural aspects of Javanese Islam.

The unbalanced analysis on Javanese Islam results in the unfair and misrepresented narratives of this matter. Javanese Islam tends to be perceived as unimportant and peripheral in the configuration of Islam as a whole. Such a misconception creates further multiplier effect that the Javanese Islam can be regarded an inauthentic distorted and downgraded variant of religion. In contrast, Islam in the place of its origin, Arabian Peninsula, tends to be regarded as authentic and pure religion. Such a viewpoint did not take geographical determination into serious account when explaining Javanese Islam, something that determines the subtle and continuous metamorphosis Islam has been undergoing in the far-away land from its place of origin. It is likely that such a perception was taken from the one-sided sources of information during the time Geertz undertook his field research. This misperception, however, leads to an essentialist judgment that undermines the objective reality of Javanese Islam at work.

At the other extreme of the pole, there are scholars who defend the degree of "Islamicity" of the Javanese Islam. Mark R Woodward is a case in point of the proponent of this pole. He argues that the Javanese Islam is not a distorted or downgraded version of authentic

\footnotetext{
8 Samuel P. Huntington, The Clash of Civilizations and the Remaking of World Order (New York: Simon and Schuster, 1996).

9 James Duncan and David Ley, "Structural Marxism and Human Geography: A Critical Assessment", Annals of the Association of American Geographers, Vol. 72, No. 1 (March 1982): pp. 30-59.
} 
Islam just because this religion is accompanied by local elements such as slametan rituals. ${ }^{10} \mathrm{He}$ seems to stand in firm opposition to Geertz. As in any other part of the Muslim world, he argues, Islam faces the complexity of translating its message into the local way of life. In this context, the slametan ritual- to which Geertz attributes as a typically syncretistic ritual-is a manifestation of normative piety as sanctioned in its textual sources such as the Qur'an and the Prophetic sayings (Hadith). The way Woodward builds his argument, nevertheless, is poorly founded due to the fact that acculturation is at work when one explains the reality of Javanese Islam. It is clear from his antithetical position to Geertz that Woodward undermines the long term process of acculturation of Islam into the web of Javanese culture that makes this religion unique to its counterparts in any other parts of the world.

Outside of the two poles above, there can be found scholars who try to stand in a fair and neutral position. One of them is Marshall G.S. Hodgson, a historian from the University of Chicago. In his book, The Venture of Islam (1974), he severely criticizes Geertz's conception of Javanese Islam as partially influenced by modernist vision of Islam. Hodgson further argues that:

"Unfortunately, its general high excellence is marred by a major systematic error: influenced by the polemics of a certain school of modern Shari'ah-minded Muslims, Geertz identifies 'Islam' only with what that school of modernists happens to approve, and ascribes everything else to an aboriginal or a Hindu-Buddhist background, gratuitously labelling much of the Muslim religious life in Java 'Hindu'. He identifies a long series of phenomena, virtually universal to Islam and sometimes found even in the Qur'an itself, as un-Islamic; and hence his interpretation of the Islamic past as well as of some recent anti-Islamic reactions is highly misleading". ${ }^{11}$

The quotation above presents Geertz's glaring carelessness in seeing the reality of Javanese Islam. This means that Geertz, as a scholar and anthropologist, had been unable to cope with problems of distancing himself epistemologically from the object of his study: Javanese Islam. Quoting his analysis on the Javanese Islam, Hodgson

\footnotetext{
${ }^{10}$ Mark R. Woodward, “The Slametan": Textual Knowledge and Ritual Performance in Central Javanese Islam”, History of Religions, Vol. 28/No. 1 (Aug 1988): pp. 54-89.

11 Marshall G.S. Hodgson, The Venture of Islam: Conscience and History in a World Civilization, vol. 2 (Chicago: Chicago University Press, 1974), p. 551, footnote \# 1.
} 
argues that "When the gentry adopted Islam, these traditions were woven into Sufism, which they enriched and endowed with a distinctively Javanese beauty". ${ }^{2}$

Apart from scientific approach he employs, Geertz is also mistaken in making the trilogy of Javanese religion: santri, abangan and priyayi. As much has been written on this, the mistake lies at his consistency in making his argument on the basis of social category, not religious one. From the three categories of Javanese religion, it is only santri and abangan that are classified on the basis of religious category, while priyayi is made based on social class category. ${ }^{13}$

It is quite surprising to see the fact that regardless of weaknesses in Geertz's analysis, his influence over the later generations of scholars who studied Javanese Islam continues. Geertz seems to have established himself as the leading authoritative source in the studies of Javanese Islam in the 1960s and long after. In the studies of Islam and Java, his influence has been so tremendous that no one can avoid his name when studied this subject. His name cannot only be found in anthropological studies on Islam and Java from which his academic reputation starts to boost, but also in other studies such as Islamic studies, politics, sociology as well as other interdisciplinary studies. In other words, the studies of Javanese Islam seem incomplete without referring to his name as well as his scholarly works.

\section{The Transformation of Javanese Islam}

As an academic subject, Javanese Islam is not a closed entity and immune to change. Along the course of time, Javanese Islam has undergone a process of evolution and transformation into something different from the past, either at the surface level or its core essence. Referring to the Javanese Islam as identical with what Geertz has

\footnotetext{
12 Ibid., p. 551.

${ }^{13}$ For further details on this, see Harsja W. Bachtiar, "The Religion of Java: Sebuah Komentar", in Clifford Geertz, Abangan, Santri, Priyayi dalam Masyarakat Jawa, translated by Aswab Mahasin (Jakarta: Pustaka Jaya, 1989).

13 The fact that the Javanese Muslims cannot be characterized by a discrete identity seems to have confirmed what Erich Kolig's theoretical assumtion. In his opinion, Muslims especially in Central Java cannot be demarcated according to black-and-white fault line-especially among the moderate and radical ones-is because the religious identity among them is so fluid and unstable. For further description on this, see, Erich Kolig, "Radical Islam, Islamic Fervour, and Political Sentiments in Central Java, Indonesia", European Journal of East Asian Studies, Vol. 4/No. 1 (2005): pp. 55-86.
} 
defined in the 1960s is undoubtedly irrelevant to this time. This underlines the fact that Weberian approach that treats Javanese Islam as a closed entity untouched by change is theoretically unacceptable.

It seems that what is meant by Geertz as Javanese Islam covers only abangan variant, not santri. Geertz uses the label agama Jawi (the religion of Java) for abangan or kejawen group, while he uses the term agami santri for the practicing or devout Muslims. For santri, the label Javanese Islam might exempt themselves from this group because they apply different system of rituals. Ricklefs uses the term kaum putiban (white community) for santri. In his opinion, it is the devout Javanese Muslims who labelled themselves to be golongan putihan (the whites). ${ }^{14}$ This group was in general characterized by better social and economic status than the abangan counterparts; usually they are more wealthy, wear better clothes, have bigger houses, live more orderly life, avoid opium, the provision of better and higher education for their kids, and more disciplined.

Geertz's depiction of Javanese Islam above, nevertheless, raises a further critical evaluation: is it the case for today's context? Is Geertz's depiction still relevant? Perhaps this is one of the most critical loopholes in Geertz's analysis of the Javanese Islam. The denotative meaning as contained in the term "Javanese Islam" as the kejawen or abangan variant needs further evaluation for today's context, due in part to the fact that the landscape of Javanese Islam has undergone a significant transformation which is far different from its description of the past. First of all, the identity of kejawen or abangan is not a closed and discrete entity which demarcates from other variants, especially the santri community. ${ }^{15}$ These two groups are to a large extent not demarcated by a black-white and firm fault lines. The time-span of more five decades since Geertz and his colleagues undertook their research projects in "Modjokuto" (Pare, near Kediri in East Java) has seen significant changes in identity configuration among Javanese

14 MC. Ricklefs, Islamisation and Its Opponents in Java: A Political, Social and Religious History, c. 1930 to Present (Singapore: NUS Press, 2012), pp. 49-51.

15 The fact that the Javanese Muslims cannot be characterized by a discrete identity seems to have confirmed what Erich Kolig's theoretical assumtion. In his opinion, Muslims especially in Central Java cannot be demarcated according to black-and-white fault line-especially among the moderate and radical ones-is because the religious identity among them is so fluid and unstable. For further description on this, see, Erich Kolig, "Radical Islam, Islamic Fervour, and Political Sentiments in Central Java, Indonesia", European Journal of East Asian Studies, Vol. 4/No. 1 (2005): pp. 55-86. 
Muslims in which the process of identity exchanges between the two has occurred. This leads to the making of an in-between Muslim identity, analytically blurred, signifying that there is no one-fits-all religious identity in among the Javanese Muslims.

Second, the dichotomy of abangan-santri has often been adopted to explain how stream politics (politik aliran) works in the context of Indonesia's early politics after independence (Carnegie, 2010). During the consecutive three decades-the 1950s, 1960s and 1970s-the explanation of politik aliran might be applicable in analyzing the ideological and political contest between the two groups. In reality, the explanation of politik aliran (in the sense of political contest between the two) is no longer relevant in so far as democracy has been applied in this country that enables all elements of society take part in an open electoral competition that reaches the grass-roots. Furthermore, the santri community-both the modernists and traditionalists-has transformed ideologically in such a way that their political platform is no longer different from that of the abangan community: both have arrived at the same agreement to uphold Negara Kesatuan Republik. Indonesia (NKRI, Unitary Form of the Republic of Indonesia), Pancasila, UUD 1945 and Bhinneka Tunggal Ika.

Third, the deepening proses of Islamization in Java has eroded the existence of kejawen community on the one hand and boosted quantitatively the existence of the santri at its highest profile on the other. This is perfectly in line with what MC Ricklefs and Hefner conclude in their works respectively, that the deepening process of Islamization has been intensified particularly during the second half of the New Order regime and its aftermath up until more recently. ${ }^{16}$ Due to this reason, it is hardly found an ideological contest between the abangan and santri in the public realm as it was in the past as a result of closer ideological views between the two.

The reality of decrease of kejawen community has been confirmed by several survey indicating the increase of normative observance and obedience among Indonesian Muslims. A survey undertaken by Riaz Hassan, for instance, indicates clearly how nominal Muslims in

16 Ricklefs, Islamisation and Its Opponents in Java, pp. 274-317. See, also, Robert W. Hefner, Civil Islam: Muslims and Democratization in Indonesia (Princeton, NJ: Princeton University Press, 2000), p. 84. 
Indonesia have been replaced by the practicing Muslims. ${ }^{17}$ According to this research, significant number of Indonesian Muslims (96\%) claim that they performed five daily prayers, fasting during Ramadhan month (99\%), paying alms giving, and other normative observance. ${ }^{18}$ The observance of Indonesian Muslims is above any other Muslim countries in the world, such as Malaysia, Egypt, Iran, Turkey, and even Saudi Arabia itself. This survey, thus, indicates the thesis of deepening process of Islamization among Indonesian Muslims which implies the increase of devout Muslims on the one hand, and the decrease of kejawen Muslims, on the other.

Another survey was carried out by PPIM UIN Jakarta in 2006 and 2010, as cited by Ricklefs, which shows that there was a significant bulk of Javanese Muslims in Central Java, Yogyakarta and East Java, who observed five daily prayers and alms giving. In 2006, there was $90 \%$ of Muslims in Java that claimed to observe five daily prayers routinely, while it decreased a little bit in 2010 to $89 \%$. While $93 \%$ of Muslims in Java claimed that they paid alms in 2006, the number increased a bit in 2010 to $94 \% .^{19}$ Furthermore, another local survey undertaken in a sub-district Jekulo, Kudus, Central Java, in 2007 reveals that $81 \%$ of Muslims said that they carried out the five daily prayers and alms-giving. Lastly, in Kediri, the number of Muslims who observe rituals based on a survey in the same year indicates that the number of Muslims who did five daily prayers reaches $92 \%$, while those who paid alms-giving was $95 \% .{ }^{20}$

The Islamization process among the Javanese Muslims-both quantitatively and qualitatively speaking-indicates the successful penetration of this religion into the heart of socio-cultural life of Java. The 5 century time-span of Islamization since this religion was introduced to Java has created internal dynamics and tension among the Javanese. The relative success is partly attributed to the acculturation machine that works at the socio-political and cultural level. Unlike Islamization in other parts of the world where the encounter of two cultural elements is colored by military conquest, the

\footnotetext{
17 Riaz Hassan, "On Being Religious: Patterns of Religious Commitment in Muslim Societies", The Muslim World, Vol. 97 (July 2007): pp. 437-478.

18 Ibid., p. 452.

${ }^{19}$ Ricklefs, Islamisation and Its Opponents in Java, p. 448.

${ }^{20}$ Ibid., p. 449.
} 
conquest of Java is accompanied by cultural dialogue and acculturation that paves the way for Islam to be accepted more widely by the Javanese community as a major religion of this island.

Another side of the Islamic conquest of Java confirms the working of Sufi tradition that becomes the catalyst for local spirituality. The majority of Javanese seems to be more esoteric while avoiding exoteric dimension with black-and-white and legalistic vision of religion. Such a characteristic finds its relevance in Sufism in Islamic tradition with the emphasis on inner-dimension of human life. In this context, Ricklefs maintains that

"It is important to note that such evidence as we have from the early centuries of Islam in Java supports the view that mysticism Sufism - was the dominant style of Islam there. The two sixteenth century manuscripts that survive are both mystical. Later Javanese legends about Islamization tell of people with mystical insights and magical powers. The transition from mystical HinduBuddhism to mystical Islam was thus presumably eased by conceptual continuities". ${ }^{21}$

The Sufi tradition of Javanese Islam, to which Ricklefs refers as the mystic synthesis, is characterized by three prominent features as follows. ${ }^{22}$ The first feature is the sense of Islamic identity due to the fact that this religion is the most conceivable religious identity. In this context, it is said that most of the Javanese aristocrats such as Sultan Mangkubumi (Hamengkubuwono I, 1749-92), the first Sultan of Yogyakarta, take Islamic mysticism and piety into serious consideration as his religious identity. The second feature is the fulfilment of five pillars of Islamic ritualistic observance-the confession of the faith, five daily prayers, alms giving, Ramadhan fasting and pilgrimage to Mecca for those who are able to do so. The third feature is the acceptance of local spiritual forces such as the queen of the Southern Ocean (Ratu Kidul).23

Islamization among the Javanese has implicitly threatened the extinction of all related aspects of abangan or kejawen. As widely known, kejawen or abangan comprises non-practicing Muslims. Even though

\footnotetext{
21 MC Ricklefs, Polarising Javanese Society: Islamic and Other Visions (c. 1830-1930) (Singapore: NUS Press, 2007), p. 3.

22 Ibid., p. 5.

23 Ibid., p. 7.
} 
they proclaim as Muslims, they want to detach from the identity of the putihans or santris. This extinction can lead to the loss of abangans' narratives of belief system and rituals from the grand narrative of Javanese Islam. This reality has demonstrated the weak self-defence mechanism of the kejawens in facing the intense invasion of the santri's worldview. What happens at the grassroots, nonetheless, the Islamization has been achieved in tandem with acculturation as represented in the slametan rituals which is cyclically done through steps of life. ${ }^{24}$

In the spectrum of Javanese Islam, the slametan rituals undoubtedly represent a creative novelty invented by elder generation of Muslim propagators in order to attach Islam into the structure of Javanese religious life. As an invented practice, the slametan does not take roots explicitly from its sacred texts, the Qur'an and Hadith. Prior to being fully accepted and practiced by Javanese Muslims, the major bulk of slametan elements were occupied by the non-Islamic symbols such as offerings and sayings or prayers spelled out in old Javanese language. In addition, the rituals were led by a local Javanese dukun (most respected figures in the hierarchy of society due to their mastery in old Javanese wisdom). It is not until lately that the slametan have commonly been led by kiai (Muslim preachers or clerics) who are well versed in Islamic knowledge and are usually pesantren (Islamic boarding school) graduates. It is they who have replaced all Hindu-Buddhist derived elements with Islamic ones taken from sayings and prayers of the Qur'an and Hadith.

Santris themselves have responded to this acculturation process in various ways. For the traditional santris, the acculturation has been regarded as intercultural marriage between the two: normative Islam and local culture which can form an accepted hybridity of Javanese Islam. Since the outset, the traditionalists do not see such an acculturation as contradictory to the orthodoxy of normative Islam. They even utilize the cyclical events of human life as a part of Islamization projects by replacing the major parts of the slametan with Islamic elements such as the replacement of Javanese prayers with Arabic ones. They also remove the sacred meaning of sesajen (offerings) into something artificial.

${ }^{24}$ Masdar Hilmy, "Islam and Javanese Acculturation: Textual and Contextual Analysis of the Slametan Ritual” (Unpublished MA Thesis, Montreal: McGill University, 1999). 
For the Muslim modernists, however, the acculturation of Islam into Javanese culture is regarded as an unfinished business in terms of Islamization process. For them, the tradition of slametan ritual represents the mixture of kejawen elements with those of Islam, something anthropologically impossible to mix in their mind due to contradictory nature within them. To the majority of Muslim modernists, the slametan tradition does not represent an Islamic way of life because it is already contaminated with non-Islamic or local elements. In their opinion, the slametan rituals do not have strong and sound justification from the Islamic texts such as the Qur'an and Hadith. Due to this reason, the majority of Muslim modernists would classify the slametan rituals as innovation (bid'ah) which is considered theologically illegal in Islam.

Among the abangans, such rituals as slametan represents the core tradition initiated fully in Javanese ways and worldview, part of which is Javanese offerings and utterances which are believed to have spiritual power. ${ }^{25}$ With the passage of time, village kiais - the most of whom are the graduates of pesantren-have Islamized gradually the major parts of the slametan by replacing the Javanese elements with those of Arabic origins. As a consequence, the content and form of those rituals become gradually more Arabicized (or Islamicized) thanks to the creative hands of those kiais. In this context, it is hardly found in today's context any slametan ritual performed in pure kejawen ways, thereby kejawen tradition has been transformed and, as a result, marginalized in such a way that it is in jeopardy.

\section{The Reconstruction of Javanese Islam}

On the basis of the explanation above, the definition of what constitutes Javanese Islam cannot avoid noting the transformation which this variant of religion has undergone so far. To defend the two spectrums above- those who simplify Javanese Islam as an abangan or kejawen religious entity and the proponents of normative Islam-is no longer realistic, due to the change of religious configuration that has changed the empirical reality of Javanese Islam. The entity of Javanese Islam, therefore, is no longer identical with the same entity in the 1960 's or 1980's. To reduce the Javanese Islam into a mere kejawen or abangan variant of religion, therefore, is no longer valid because there

25 Ibid. 
are a lot of younger generation of abangan who have been more deeply Islamicized (becoming practicing Muslims). The kejawen religious system does not have a strong self-defense mechanism in facing the waves of Islamization process. As a consequence, their belief system is under serious threat and this can lead to the replacement of their ritual system with santri rituals such as five daily prayers, fasting during Ramadhan, paying alms giving, and pilgrimage to Mecca.

Even though the process of Islamization has been achieved at the most intensive level than before, it does not mean that there is no cultural resistance at all among the grass roots. As written by Ricklefs, the influence of Keraton (Mataram) tradition has been the main obstacle to the Islamic movement's influence at deeper levels of the society. ${ }^{26} \mathrm{~A}$ report was made that the ideas of black magic supported by the Keraton tradition has served as the barrier of Islamic penetration that leads to associationism (shirk) among the Muslims. Javanese kings are believed to have an intimate relationship with spirits such as Ratu Laut Kidul and spirits of Merapi mountain and Lawu mountain. A series of typically kejawen festivals are still being held until today such as washing all sacred regalia of the kingdom (pusaka) during the first month of the Javanese calendar, a tradition that is not found in any Islamic tradition elsewhere in the world. ${ }^{27}$

Despite the fact that the Islamization process has been carried out at the most intensive level, a series of small group of abangan choose to defend. In some cities, such as Jombang, Kediri, Nganjuk, Tulungagung, Trenggalek and other cities in East Java there still can be found some kejawen groups such as Sumarah, Sapto Dharmo, Jawa Dipa, and many others. ${ }^{28}$ This means that the Islamization process cannot convert a small number of abangan and they choose to stay with their old tradition of kejawen. This small group of abangan, nevertheless, is unable to offer the contending vision of the santris in terms of rituals and belief system. It is understandable that the abangan does not show much development; rather, their practices have been dying among the majority of practicing Muslims. This condition is totally different from the condition of the 1950's and the 1960's where the spiritual and religious realm was dominated by kejawen belief. The younger

${ }^{26}$ Ricklefs, Islamisation and Its Opponents in Java, p. 594.

${ }^{27}$ Ibid., p. 560.

${ }^{28}$ Niels Mulder, Mysticism in Java: Ideology in Indonesia (Yogyakarta: Kanisius, 2005), pp. 75-81. 
generation of kejawen community who turned to be santris acknowledges that there is no regret in regards to their internal conversion and they are even proud of their parents who also converted prior to their death.

On the contrary, considering Javanese Islam as an identical version of normative Islam or Islamic orthodoxy undoubtedly ignores the acculturation that makes Javanese Islam a unique and distinctive version of religion. To hold the view that the slametan tradition represents the normative or pure version of Islam denies the existence of Muslim modernists who reject it, or a contradiction to the empirical existence of Islam outside of Java and in the rest of the world. It is a matter of fact that Javanese Islam is made of culturally blended elements that makes it "exotic" and distinctive. Due to this reason, various types of acculturation and chemistry between Islam and local tradition as manifested in the slametan rituals represents the reality on the ground.

Referring to Javanese Islam, therefore, cannot be done in terms of practicing or non-practicing Muslims. Javanese Islam is a variant of Islam in its totality, whose cultural manifestation and features are distinctively different from what Geertz and Woodward have constructed before. Javanese Islam, to a larger extent, is shared by both santris and abangans in its cultural identity or ritual practices. Dichotomizing the abangans from the santris, thus, is no longer relevant for today's context. This is so not only because there is a great deal of "santrinized" abangans, but also because the majority of (traditionalist) santris have shared rituals and festivals owned only by the abangans in earlier times.

The same assumption may also apply to the Muslim modernists. Their interaction with the traditionalists as well as the abangans may have led to the reconsideration of their cultural strategy in approaching the Javanese society in general. The adoption of a cultural strategy in doing propagation (dakwah), for instance, has helped in moderating their unbending theological standpoints on various types of Javanese Muslim rituals (PP Muhammadiyah, 2004). ${ }^{29}$ Some of them have even

29 The issue of culture received its prominence among Muhammadiyah members particularly after the $43^{\text {rd }}$ Muktamar in Aceh in 1995. This is because this organization was criticized by its members such as Kuntowijoyo as being too rigid and dry culturally as a result of purificationist nature contained in its mission. It is within its 2005 congress in Malang. 
wedded some dimension of Javanese culture into their religious practices by desacralizing the Javanese types of rituals as a merely cultural. This means that they incorporate some popular Javanese festivals such jaranan or reog performance by disentangling the sacred symbolic meanings from their performance. ${ }^{30}$

It must also be acknowledged the Islamic acculturation into Javanese culture contributes to the waning of kejawens on the one hand, and Islamic identity of santris on the other hand. Javanese Islam is thus an eclectic identity comprising the relative mixture of normative Islam and local Javanese elements at once which is never monolithic and black-and-white. Within the acculturation process there is a neverending process of cultural negotiation between the two, colored by an overlapping consensus; the santris borrow the religious identity of the abangans and vise-versa, the abangans incorporate into the identity of the santris. What is meant by religious identity in this context is cultural and theological features ranging from physical appearance, cultural attributes to religious rituals. It is due to this reality that sorting the abangans and the santris is almost impossible.

On the socio-political level, this mode of acculturation also contributes to the melting dichotomy of secular-nationalist and religious-santris in terms of stream politics (politik aliran). To use the perspective of stream politics to explain the present-day political context is hardly relevant, even though there are few politicians who keep employing the argument of stream politics to attract the minority of abangans in a limited direct local election (Pilkada) by remaking the identity politics. The use of stream politics, nevertheless, receives its serious contender among the society by the existence of rational choice tendency. The melting of stream politics can be seen, among others, in the establishment of religious units under abangan-based political party such as Megawati's Partai Demokrasi Indonesia Perjuangan (PDIP) and the involvement of young santri background politicians in non-santri based political parties. ${ }^{31}$ In short, there is no longer ideological demarcation

${ }^{30}$ For further information on Reog performance, see, for instance, Margaret J. Kartomi, "Performance, Music, and Meaning of Reyog Ponorogo", Indonesia, 22 (October 1976): pp. 84-130.

31 Megawati's PDI Perjuangan established a Muslim unit called Baitul Muslimin Indonesia. Its organizational structure is taken from mainstream religious organizations such as Nahdlatul Ulama (NU) and Muhammadiyah. Each Chairman respectively, Said Aqiel Sirodj and Din Syamsuddin, serve as its advisors, in addition to Megawati herself. 
separating the abangans from the santris as the acculturation (or Islamization) has more intensively been taking place at all levels in the society.

\section{Towards A Hybrid Identity}

Becoming an abangan or santri in the post-Geertz era represents the making of a religiously hybrid identity. In the context of Geertz, to become an abangan means he/she cannot become a santri at the same time. At that time, a pure and puritan abangan, was hardly a practicing Muslim, but rather only a nominal Muslim. A Javanese with such an identity did not have any option except putting on his/her Javanese attributes in abangan sense with all integrity, starting from such trivial things as dress-code, cultural hobbies such as bird keeping and traditional Javanese music (klenengan), ${ }^{32}$ to the most fundamental aspects of Javanese identity such as rituals which were not shared with the santris, especially the modernist Muslims.

Likewise becoming a santri, one had to distance oneself from any type of identity in kejawen sense, from trivial things to the most substantive ones. $\mathrm{He} / \mathrm{she}$ had to enter into the realm of santri identity in its totality as a practicing Muslim. Anyone associated with santri identity was required to observe mandatory rituals as contained in the five pillars of Islam (lima rukun Islam) such as confession of the faith, five daily prayers, fasting during Ramadhan, alms-giving, and pilgrimage to Mecca. They, on the other hand, could hardly go across the border of the abangan identity such as klenengan tradition, kejawen ritual system, and the like. Between the two religious identities lies a bold fault-line dividing each of them in order not to enter into one another. Once one crossed the border, he/she might be accused by his/her fellows as disloyal to his/her traditional identity.

Unlike in the past, becoming abangan or santri in today's context does not necessitate a stringent code of conduct that determines the clarity of religious identity. Becoming abangan or santri is a matter of whatever-you-like mentality or voluntary action among the Javanese. In some cases, becoming a Javanese Muslim is half abangan and half santri or vise-versa. A Javanese Muslim from abangan background now is found to be no longer contingent upon the stringent code of conduct prescribed by his community, whereas at the same time

32 Marc Benamou, RASA: Affect and Intuition in Javanese Musical Aesthetics (Oxford: Oxford University Press, 2010). 
he/she can subscribe to the santri ritual system. Or the other way around, a Javanese Muslim derived from santri background can enter into the "grey area" formerly forbidden for him/her to enter, such as the tradition of klenengan, calendrical calculation (petungan), slametan ritual and so forth.

Being a Javanese Muslim, therefore, has to do with a hybrid religious identity; the juncture where overlapping elements are mixed. This is not merely a matter of becoming abangan or santri in a totalistic and strict way; rather, it is becoming something in-between the two extreme poles, something almost impossible at the time of Geertz or beforehand. Suffice it to say that the variants of becoming Javanese Islam are multiple and diverse, not monolithic like in the past. This is so because the acculturation and transformation of Javanese Islam is continuously flowing and taking place with the passage of time.

The continuous transformation of Javanese Islam cannot be dissociated from the ideological contest in the public sphere for maintaining and defending any particular religious identity. The public sphere serves as an open space for championing and influencing any religious ideology among the society. The public sphere offers constructive and productive mutual exchanges for the enrichment of each identity. For those who are involved, the public sphere is not perceived as battleground for negation of one another. It is within this context that such a productive acculturation leading to identity exchanges among abangans as well as santris is continuously taking place.

The ideological contest in the public sphere has resulted in the shift in terms of religious identity among the Javanese Muslims. ${ }^{33}$ The phenomenon of internal conversion is likely to be one of the consequences of that contest, particularly among those abangans migrating to santri identity. In this case, a committed abangan may become another committed santri in its literal sense, so that they may disentangle all cultural aspects related to abangan identity they have had subscribed in the past. In the context of such an identity shift, the converts perceive what they have experienced as the process of hijrah (migration) from a particular religious identity to a totally different one. Once an abangan has committed to become a santri, it means that

33 See, for instance, Sutiyono, Benturan Budaya Islam: Puritan \& Sinkretis Jakarta: Penerbit Buku Kompas, 2010). 
he/she is ready to give up his/her old identity and in order to subscribe to a completely new one by becoming a practicing Muslim.

The phenomenon of such an internal conversion can easily be found in societies reputably known as the basis of abangan such as Solo, Sragen, Sukoharjo, Boyolali, Temanggung and the like. ${ }^{34}$ The reality of ideological migration is usually driven by a more intense process of dakwah and Islamization carried out by individuals or social organizations whose religious vision tends to be salafi. As has been known, those areas mentioned above are the place where militant organizations grow and develop significantly such as Majlis Tafsir AlQur'an (MTA), Jama'ah Tabligh, Jama'ah Anshorut Tauhid (JAT), Hizbut Tahrir Indonesia (HTI) and others. It seems that these organizations treat those regions as the basis of dakwah. This is why the massive growth and development of new emerging santris in those regions is incomparable to other regions in Java, due mainly to the aggressive activities of dakwah undertaken by those salafi-oriented individuals and social organizations.

In terms of hybrid identity, a female informant in Solo named Mrs. Nunik, for instance, expressed her concerns about being "religious" by combining the identity of both abangan and santri at once. Her hybrid identity was revealed from the way she dressed in hijab, even though she was a nominal or non-practicing Muslim. As a convert from Christianity since she got married, she thought that the point of being religious is to be a good person. She argued that there is no point in embracing a particular religion if he/she cannot become a good human regardless of ritual practices he/she observes. She identified herself as a non-practicing Muslim, despite the hijab she wore like other Muslims in general. When she died, she did not want to be dressed like the dress code of typically Muslim deceased (pocong) during her funeral because she thought that this way is frightening. She wanted to be dressed in a priyayi (aristocrat) fashion like her father at his funeral since he was a dalang (shadow puppet performer). She wants to remain to look beautiful even though she is dead. ${ }^{35}$

34 Muhammad Wildan, "Mapping Radical Islam: A Study of the Proliferation of Radical Islam in Solo", in Martin van Bruinessen, Contemporary Developments in Indonesian Islam: Explaining the "Conservative Turn" (Singapore: ISEAS, 2013), pp. 190-223.

35 Interview with Mrs. Nunik, 17 April 2017. As a sociological background, Mrs. Nunik is a street vendor in Solobalapan railway station, Surakarta. She is selling drinks such coffee and tea, cakes and some other traditional food for passengers passing by. She occupies a narrow food stall of $2 \mathrm{~m}^{2}$ with three other vendors next to her; one of them 
It seems that what drove Mrs Nunik and a great deal of other female Muslims to wear hijab is not her intrinsic motif per se; rather, it was driven by the force of geographical determinism in doing so. It is a matter of fact that most of areas in Java has been swept by the waves of Islamization undertaken by salafi individuals or organizations as mentioned above. What these individuals and organizations are doing so far is creating a new mode of normality in terms of religious life significantly different from the past. As found elsewhere in Java, there are more female Muslims covering their bodies with Muslim dresscode (busana Muslimah) such as hijab which can be easily noticeable compared to their fellow male Muslims. This phenomenon nevertheless does not automatically indicate that they are all practicing Muslims; some of them may be yes. They subscribe to particular dresscode because they feel that the condition forces them to do so.

The opposite way of internal conversion, i.e. from santri to abangan, is hardly found, due to the fact that being santri in the end of life for the Javanese is commonly understood as a repentance for whatever happened in their past. In this context, what is possibly the case is not an internal conversion, but the phenomenon of adopting the abangan life style by santris. More precisely, the santris are only empathetic towards the way the abangan live, such as the dress-code according to the Javanese tradition, bird keeping, the music tradition of klenengan, the slametan rituals and the like. This means that the adoption of religious identity among the santris to the Javanese identity runs only at the surface, not at the substance level. This is so due to the fact that becoming a fully committed abangan means that one has to be a nonpracticing Muslim in its conventional sense, because they have their own ritual system which differs significantly from the santris' ritual system.

Java has long been the battleground for ideological contest among different as well as within the same religious traditions. The contests over ideological and religious values are still taking place even though on the surface level the bulk of Javanese continues to speak up about religious harmony. It reaches its momentum in the aftermath of New

is Christian. The other three fellow vendors wear the same hijab as Mrs Nunik wears, but their religious identity is slightly different to each other. One of them, called Mrs Sunarmi, claims herself to be more devout Muslim than Mrs Nunik by doing five daily prayers, fasting during Ramadhan month and paying alms. She wishes that she can go pilgrimage to Mecca someday by saving money from what she is earning as a vendor. 
Order regime where the public sphere welcomes all types of utterance and articulation of extreme different viewpoints on religious issues previously discouraged and banned by the regime. The harsh contest particularly can be felt through social media such as whatsapp application where members from different religious groups are involved in the exchanges of ideas over religious issues. It is difficult to determine who won the battle provided that each individual in particular membership of social media group can now examine and challenge the established tradition of religious orthodoxy. Suffice it to say that everybody can now enjoy freedom of expression which was too luxurious during the New Order regime.

The ideological and religious battle amounts to unstable eclecticism in identity among the Javanese Muslims. Cultural borrowings among different religious identities are thus highly likely to happen, even though the reasons behind these borrowings during these days are not always easily identifiable. This phenomenon is commonly characterized as assimilation or acculturation process in sociological studies and social sciences. ${ }^{36}$ Adoption to new religious identity is the most possible way of negotiation in order to avoid social conflict. This seems to be the case with the majority of converts among the Javanese Muslims. At other occasions, however, the process of negotiation can result in tension and resistance. In this context, the creation of hybrid identity among the Javanese Muslims is possible as a result of negotiation and reception.

\section{Conclusion}

As demonstrated above, defending the old narrative about Javanese Islam, is not only irrelevant for today's context in the post Geertz era, but also theoretically misleading. This is so due to the

\footnotetext{
36 Many observers sometime lump the term assimilation together with acculturation, which are different to each other in social sciences. Following Alba and Nee, Herbert J. Ganz defines assimilation as "the decline of an ethnic distinction and its corollary cultural and social differences". Acculturation, however, refers to the same thing as assimilation at the cultural, not social, level. Moreover, both terms have something to do with social mobility of people (usually immigrants). Whereas acculturation takes place at the immigrants' initiative to integrate to local culture, assimilation is taking place when immigrants are being accepted by the non-immigrants whom they seek to join and it usually runs slowly but naturally. For the differences of the two terms, see, among others, Herbert J. Ganz, "Acculturation, Assimilation and Mobility", Ethnic and Racial Studies, Vol. 30/No. 1 (January 2007): pp. 152-164.
} 
inability of Geertz's conception on the Javanese Islam to accommodate the most current narratives on the tremendous shift, transformation and evolution of meaning as experienced by the Javanese Islam. In the Geertz era, referring to the entity of Javanese Islam comprises only the two variants of his trilogy, abangan and priyayi; in today's context it can also comprise the whole variants of Muslims, including the santris. This reality is attributed to the mixing of religious identities among all variants of the Javanese Muslims which overlap one another, so that the borrowing and adopting of religious identity among all elements of the Javanese is likely to happen.

Furthermore, the grand-narratives of Javanese Islam as espoused by both Geertz and Woodward contain serious laxities, both at conceptual and at empirical levels. Their conception of Javanese Islam follows a zero-sum pattern; on the one hand Geertz and his followers identify Javanese Islam as a syncretic religious entity which is distorted from normative Islam. On the other hand, Woodward argues against Geertz by arguing that the entity of Javanese Islam represents an equally identical, standardized piety as prescribed by the normative Islam elsewhere, especially in its place of origin.

As this article has demonstrated, both poles mentioned above are theoretically and empirically unfounded due in part to their inability to accommodate the comprehensive portrayal of Javanese Islam whose characteristics are fluid, dynamic and multivocal. The continuous acculturation and islamization among the abangans that leads to the transformation of religious identity of Javanese Islam is the main explanation behind the changing dynamics of Javanese. Last but not the least, the acculturation and Islamization is responsible for making the hybrid identity of Javanese Islam as well as the phenomenon of internal conversion among the Javanese Muslims. [] 


\section{References}

\section{Books and Articles}

Bachtiar, Harsja W. "The Religion of Java: Sebuah Komentar." in Clifford Geertz. Abangan, Santri, Priyayi dalam Masyarakat Jawa. Trans. Aswab Mahasin. Jakarta: Pustaka Jaya, 1989.

Beatty, Andrew. "Adam and Eve and Vishnu: Syncretism in the Javanese Slametan." Journal of the Royal Anthropological Institute, Vol. 2/No. 2 (1996): pp. 271-288.

-------. Varieties of Javanese Religion: An Anthropological Account. Cambridge \& New York: Cambridge University Press, 1999.

Benamou, Marc. RASA: Affect and Intuition in Javanese Musical Aesthetics. Oxford: Oxford University Press, 2010.

Carnegie, Paul J. The Road from Authoritarianism to Democratization in Indonesia. New York: Palgrave Macmillan, 2010.

Collins, Randall. Weberian Sociological Theory. Cambridge \& New York: Cambridge University Press, 1986.

Duncan, James and David Ley. "Structural Marxism and Human Geography: A Critical Assessment." Annals of the Association of American Geographers, Vol. 72, No. 1 (March 1982): pp. 30-59.

Ganz, Herbert J. "Acculturation, Assimilation and Mobility." Ethnic and Racial Studies, Vol. 30/No. 1 (January 2007): pp. 152-164.

Geertz, C.. The Religion of Java. New York: The Free Press of Glencoe, 1960.

Hassan, Riaz. "On Being Religious: Patterns of Religious Commitment in Muslim Societies." The Muslim World, Vol. 97 (July 2007): pp. 437-478.

Hefner, Robert W. Civil Islam: Muslims and Democratization in Indonesia. Princeton, NJ: Princeton University Press, 2000.

-------. The Political Economy of Mountain Java: An Interpretive History. Berkeley and Los Angeles, California: University of California Press, 1990.

Hilmy, Masdar. "Islam and Javanese Acculturation: Textual and Contextual Analysis of the Slametan Ritual." Unpublished Thesis, Montreal: McGill University, 1999. 
Hodgson, Marshall. The Venture of Islam: Conscience and History in a World Civilization, Vol. 2, Chicago: Chicago University Press, 1974.

Huntington, Samuel P. The Clash of Civilizations and the Remaking of World Order. New York: Simon and Schuster, 1996.

Kartomi, Margaret J. "Performance, Music, and Meaning of Reyog Ponorogo." Indonesia, 22 (1976): pp. 84-130.

Kolig, Erich. "Radical Islam, Islamic Fervour, and Political Sentiments in Central Java, Indonesia." European Journal of East Asian Studies, Vol. 4/No. 1 (2005): pp. 55-86.

Muhammadiyah, PP. Dakwah Kultural Muhammadiyah. Yogyakarta: Suara Muhammadiyah, 2004.

Mulder, Niels. Mysticism in Java: Ideology in Indonesia. Yogyakarta: Kanisius, 2005.

Ricklefs, MC. Islamisation and Its Opponents in Java: A Political, Social and Religious History, c. 1930 to Present. Singapore: NUS Press, 2012.

-. Polarising Javanese Society: Islamic and Other Visions c. 1830-1930. Singapore: NUS Press, 2007.

Sitton, John F. Recent Marxian Theory: Class Formation and Social Conflict in Contemporary Capitalism. Albany: State University of New York Press, 1996.

Stark, Werner. Sociology of Knowledge: Towards a Deeper Understanding of the History of Ideas. New Brunswick \& London: Transaction Publishers, 1991.

Sutiyono. Benturan Budaya Islam: Puritan \& Sinkretis. Jakarta: Penerbit Buku Kompas, 2010.

Whimster, Sam. Understanding Weber. London \& New York: Routledge, 2007.

Wildan, Muhammad. "Mapping Radical Islam: A Study of the Proliferation of Radical Islam in Solo." in Martin van Bruinessen. Contemporary Developments in Indonesian Islam: Explaining the "Conservative" Turn. Singapore: ISEAS, 2013.

Woodward, Mark R. “The Slametan”: Textual Knowledge and Ritual Performance in Central Javanese Islam." History of Religions, Vol. 28/No. 1 (1988): pp. 54-89. 
Masdar Hilmy

---------. Islam in Java: Normative Piety and Mysticism in the Sultanate of Yogyakarta. Arizona: University of Arizona Press, 1989. 